\title{
Negative Feedback Loop between Banks and Sovereigns in the Euro Area - Experience of the Crisis and Post-Crisis Perspective
}

\author{
Ewa Stawasz-Grabowska \\ Ph.D., Assistant Professor, University of Lodz, Faculty of Economics and Sociology \\ International Finance and Investment Department, Lodz, Poland \\ e-mail: ewa.grabowska@uni.lodz.pl
}

\begin{abstract}
The euro area crisis was characterised by a negative feedback loop between banks and sovereigns. The paper aims to indicate the genesis of this phenomenon and to determine the scale of its operation during the crisis and post-crisis conditions, as well as to identify the threats it brings. In addition, the paper discusses the actions that have been taken so far at the euro area level to reduce the feedback loop and the existing challenges in this area. The following hypothesis has been formulated: in the post-crisis conditions the euro area remains vulnerable to the sovereign-bank nexus, which in particular stems from the very legacy of the crisis, bank-based financial system, as well as incomplete reforms of the euro area institutional architecture. The research methods include data selection and evaluation as well as descriptive statistics. The main contribution of the study stems from the adoption of a post-crisis perspective and the assessment of the loop with the use of the most recent data and in relation to the crisis period. The results show that in the post-crisis period, a reduction in interconnectedness has been observed, although it has not been evenly experienced by all euro area countries. At the same time, despite some progress in recent years, institutional reforms aimed at breaking the sovereign-bank nexus are far from complete.
\end{abstract}

Keywords: bank-sovereign nexus, euro area crisis, contagion risk, safe assets

JEL: F15, F36, F45 


\section{Introduction}

From today's perspective, it can be said that the euro area countries have already left behind the period of the most acute tensions related to the course of the global financial crisis of the early $21^{\text {st }}$ century. 2018 was the fifth year in a row when positive economic growth was recorded in the euro area. An increasing number of indicators used to measure the degree of financial convergence in the euro area point to a continuing trend towards reintegration after a severe collapse during the crisis (cf. ECBb 2018). The risk of a partial breakup of the European Economic and Monetary Union (EMU) and a return to national currencies is no longer the main topic of discussion among policymakers and members of the academic community.

Nevertheless, the question remains whether the issue of the negative feedback loop between the banking sector and the public finance sector that characterised the crisis in the euro area has been resolved, and, if so, to what extent. Bilateral risk transfer between these sectors was observed at that time, which was fostered by the bank-based financial system in the EMU and institutional determinants (the transfer of the monetary policy to the central level, while leaving the responsibility for financial stability at the national level). The significance of the problem was evidenced by the fact that the motive for undertaking one of the most important reforms to change the structure of the euro area, i.e. establishing the EU banking union, was to "break the vicious circle between banks and sovereigns" (Euro Area Summit Statement 2012).

The aim of the paper is to indicate the genesis of the negative feedback loop between banks and sovereigns in the EMU, to determine the mechanism and scale of its operation during the crisis and in post-crisis conditions, as well as to identify the threats it brings. In addition, the paper will discuss current actions taken at the euro area level to reduce the feedback loop and the existing challenges in this area.

\section{The co-occurrence of banking and sovereign debt crises Phases of the euro area crisis}

The global financial crisis of the $21^{\text {st }}$ century, and especially its course in the euro area, was characterised by a strong positive correlation between the country's risk and the banking sector's risk. Governments and banks are among the most important economic entities and, as a consequence, their situations are mutually determined. During sovereign debt crises, governments implement austerity policies, which - at least in the short term - reduce economic activity, negatively affecting the banking sector, e.g., by deteriorating the quality of the banking sector loan portfolio or by a decrease in demand for loans on the part of companies and households. On the other hand, in the case of a banking crisis, governments engage public funds to rescue institutions that are too big/too important to fail, which translates into a deterioration in public finances. That is why banking and sovereign debt crises often occur one after anoth- 
er. According to the estimates of Dell'Ariccia et al. (2018, p. 5) conducted for a group of 66 countries in the period 2000-2014:

1) the probability of the occurrence of a sovereign debt crisis, provided that a banking crisis has previously occurred, is $51.0 \%$;

2) the probability of the occurrence of a banking crisis, provided that a sovereign debt crisis has previously occurred, is $22.3 \%$.

Similar results were obtained by Reinhart and Rogoff (2011), who conducted a study concerning a group of developed and developing countries using time series covering the years 1824-2009. The estimation of parameters of the multinomial logit model allowed the authors to conclude that systemic banking crises increased the likelihood of sovereign debt crises. The results proved to be stable when divided into sub-samples and were robust to changes in specifications.

De Paoli et al. (2009) studied the impact of sovereign debt crises on economic growth in a group of emerging economies in the years 1970-2000. The results of their study show that sovereign debt crises rarely occur in isolation. They are more often accompanied by banking or currency crises. In their sample, however, sovereign debt crises were more often the first to break out. The duration of sovereign debt crises and the accompanying recession depends on whether they coexist with other crises. Isolated episodes have the least severe consequences, while triple crises - debt, currency, and banking - have the most severe ones (see Table 1).

Table 1. Duration and output losses per year depending on different types of financial crisis

\begin{tabular}{|l|c|c|c|c|c|}
\hline \multirow{2}{*}{\multicolumn{1}{c|}{ Type of crisis }} & \multirow{2}{*}{$\begin{array}{c}\text { Number } \\
\text { of crises }\end{array}$} & \multicolumn{2}{c|}{ Duration (years) } & \multicolumn{2}{c|}{ Loss (per year) } \\
\cline { 3 - 6 } & 1 & $4 v e r a g e$ & Median & Average & Median \\
\hline Sovereign only & 4 & 11.0 & 10.5 & 2.5 & 2.5 \\
\hline Sovereign and banking & 10 & 8.9 & 9.5 & 13.7 & 14.3 \\
\hline Sovereign and currency & 17 & 12.5 & 14.0 & 12.7 & 11.1 \\
\hline Triple crises & 32 & 10.9 & 11.5 & 11.8 & 10.6 \\
\hline All & & & & 4.0 & 7.6 \\
\hline
\end{tabular}

Source: De Paoli et al. 2009, p. 22.

In terms of the characteristics of the euro area crisis, its onset is associated with the first tensions in the USA subprime mortgage market in 2007. Over time, it took the form of a debt crisis of some of its members. In particular, the following phases can be distinguished (cf. Cour-Thimann and Winkler 2013):

1. The financial turmoil phase, which began in August 2007. It was mainly characterised by tensions in the interbank market. At the same time, the economic outlook for the euro area was then assessed as relatively stable.

2. The financial crisis phase. The beginning of the phase dates back to $15^{\text {th }}$ September 2008 , when Lehman Brothers declared bankruptcy. In this phase, tensions in the financial market intensified, the governments of the euro area countries were forced to save banks using taxpayers' money, and the crisis also spread to the real economy. 
3. The debt crisis phase. Its beginning falls at the turn of 2009/2010. The disclosure by the Greek government of unfavourable data on the state of public finances in the country was a flashpoint. In this phase, strong increases in government bond yields were observed in the peripheral euro area countries, which de facto cut off these countries from market sources of financing and forced them to seek assistance from international creditors. The sustained decline in the yields occurred only after the announcement by the European Central Bank (ECB) of the Outright Monetary Transactions (OMT) program, allowing unlimited purchases on the secondary market of short-term sovereign bonds, which took place in July 2012.

After the announcement of the OMT programme, a lasting decline in tensions in the sovereign debt market in the euro area was observed. The improvement was also recorded in the real sphere. Since 2014, GDP growth has remained positive in the vast majority of EMU countries, and unemployment has been steadily decreasing, although it remains high in some of the countries (Greece, Spain). Assessing the situation of public finances, a substantial decrease in the ratio of general government (GG) deficit to GDP has been observed in recent years. In 2018, almost all EMU countries met the Maastricht deficit criterion. ${ }^{1}$ The debt-to-GDP ratio of the GG sector has also been systematically falling. It should be noted, however, that the ratios remain high in the countries most affected by the sovereign debt crisis (except Ireland). In particular, in 2018, the ratio exceeded the reference value of $60 \%$ more than three times in the case of Greece and twice in the case of Portugal and Italy.

\section{The essence of the feedback loop mechanism}

It is recognised that the International Monetary Fund was the first to draw attention to the occurrence of the negative feedback loop between banks and sovereigns in the EMU (cf. e.g., Mody 2009). This mechanism is characterised as a combination of direct and indirect links between these sectors and the national economy (Véron 2017, p. 8). Figure 1 presents the most important feedback loop channels.

Triggering the loop can occur through the deterioration of the performance of the banking sector (e.g., in Ireland and Spain) or the public finance sector (e.g., the case of Greece). If the first case is considered, the course of events may be as follows. The problems of the banking sector, whose stability is perceived as a global public good (Flejterski 2008, p. 17), force the government to provide assistance (e.g., in the form of direct recapitalisation), which leads to an increase in GG deficit and debt. As a result, the country's creditworthiness deteriorates, which is reflected in downgrades of government bond ratings and an increase in their yields. In an extreme situation, the government may lose access to market-based financing, and it will be forced to apply

1 Eurostat data (accessed: 28.09.2019). 
to international creditors for assistance. At the same time, falling government bond prices worsen the balance sheets of banks holding them in their portfolios. In particular, it is more difficult for banks to use them as collateral in operations on the interbank market and with the central bank. The situation in the banking sector is further complicated by the fact that the government's capacity for further support is significantly weakened.

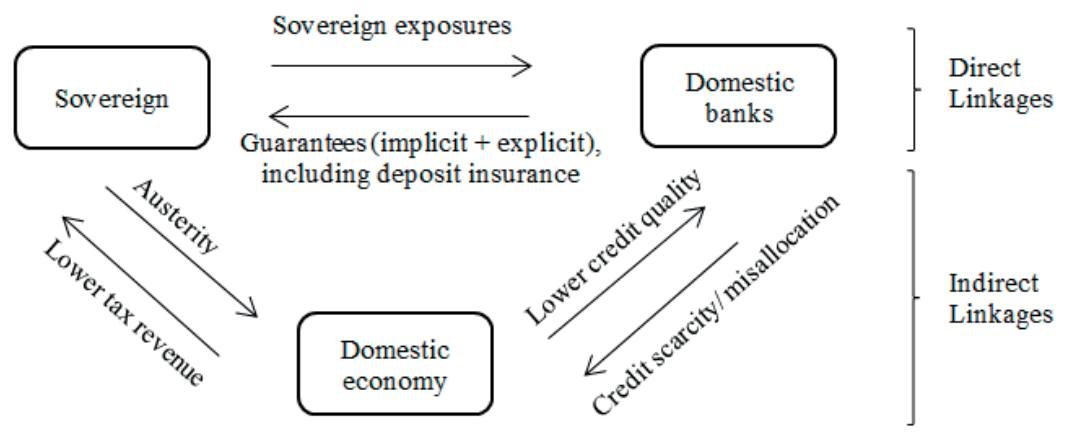

Figure 1. Selected contagion channels between banks and sovereigns Source: Véron 2017, p. 8.

As regards indirect links, the austerity policy in the form of raising taxes and introducing cuts in public expenditure limits economic activity, negatively affecting the income of enterprises and households. Moreover, the fall in government bond prices incurs losses for the households holding these bonds, and it can also translate into an increase in corporate bond yields (according to the ceiling doctrine ${ }^{2}$ ). The worsened situation of real economy entities contributes to an increase in the share of non-performing loans, reducing the profitability of banks and threatening their stability. At the same time, there is ample evidence that banking crises are associated with economic slowdowns. In a situation where banks are forced to limit lending (e.g. due to a lack of access to external financing), entities dependent on bank financing sources will limit consumption and investment, which will lead to lower tax revenues (Dell'Ariccia et al. 2018, pp. 31-32).

The operation of the negative feedback loop is reinforced by the fact that banks are susceptible to contagion, and thus the crisis can spread from one institution to the entire system. Contagion can occur directly through mutual financial exposures of institutions or indirectly through a general decline in confidence in the banking sector. In an extreme situation, depositors may start a run, which - as demonstrated by the experience of Northern Rock Bank in the United Kingdom in 2007 or Countrywide

2 As shown by the experience of emerging countries and distressed advanced economies, the sovereign rating downgrade results in cuts in the ratings of domestic debt instruments. This policy of credit rating agencies reflects the widespread belief that private debt is always riskier than sovereign debt (Luitel et al. 2016, p. 288). 
Bank and IndyMac Bank in the United States in 2008 - may also occur in highly developed countries.

To sum up, the mechanism under analysis operates as a multiplier and accelerator of vulnerabilities in the banking and public finance sectors. The described channels mutually determine and strengthen one another (Dell'Ariccia et al. 2018, p. 6). It should also be emphasised that the strength of the feedback loop depends on the type of financial system. In bank-based systems, governments will be more likely to get involved in bank bailouts. They will also be more dependent on banks as investors in the sovereign debt market. Moreover, the interdependencies should be viewed differently in normal times and during a crisis. In the first case, the government provides a financial safety net, and sovereign bonds hold the status of safe assets. However, during a crisis, these links can be a source of severe tensions (Bekooij et al. 2016, pp. 4-5).

\section{Direct links within the EMU. The operation of the feedback loop during the crisis and risk assessment in the post-crisis years}

Banks occupy a special position in the economy due to their functions. In particular, banks conduct deposit-taking and lending activities, provide operational services, and they also play an important role in the monetary policy transmission mechanism. Therefore, the links between banks and sovereigns are strong. Nevertheless, the negative feedback loop between the two sectors during the recent crisis was revealed with particular intensity in the euro area. The main reasons for the greater vulnerability of the common currency area to the occurrence of the feedback loop include the following.

1. The size and importance of the banking sector in the EMU. In 2017, the ratio of banking sector assets to the euro area GDP was around $270 \%$, i.e., three times higher than in the USA. Analysing the use of bank and market sources of financing, enterprises from the EMU countries take advantage of the former three times more often than the latter. For comparison, bank loans account for only about $30 \%$ of the external financing of American companies. The dependence on bank financing in the euro area is even more evident in the group of households as these use bank loans in $90 \%$ of cases (Singh et al. 2019, p. 3, 16).

2. The presence of large, cross-border banking groups.

3. "Deficiencies" in the pre-crisis architecture of the EMU. In particular, the following "flaws" should be mentioned: a failure to entrust the ECB with the function of a lender of last resort (LOLR), the lack of a banking union, including above all the supranational mechanism of bank resolution, and the lack of risk-sharing mechanisms such as the later-established European Stability Mechanism (cf. Navaretti et al. 2016, p. 11; Merler and Pisani-Ferry 2012, p. 2). 


\section{Risk transfer from banks to sovereigns}

The most evident way in which pressure in the banking sector can shift to the public finance sector is the (perceived) cost of bank bailouts. According to the European Commission (EC) estimates, the total value of approved aid for the banking sector in the EU in the years 2008-2017, the majority of which was addressed to institutions from the euro area countries, amounted to almost EUR 5.132 trillion, which is approx. $33 \%$ of 2017 EU GDP. ${ }^{3}$ Four forms of support dominated:

- recapitalisations,

- impaired asset measures,

- guarantees,

- other liquidity measures.

Table 2 presents the approved state aid for banks from the EMU countries broken down into support instruments. As can be seen, two forms were most often used - guarantees and recapitalisations. In the case of the former, the high value of 2008 aid is noteworthy, suggesting a quick response by the governments to the escalation of the crisis. As indicated by the EC, the majority of aid committed in the period September 2008 - December 2010 was used in the fourth quarter of 2008, as the governments sought to show their determination to restore confidence after the Lehman Brothers collapse (EC 2011, p. 37). The analysis of the data in Table 2 also confirms earlier conclusions that since 2013 a gradual reduction of tensions in the EMU can be observed. One exception is the size of approved guarantees in the years 2015-2017, which reflects the problems of Greek, Portuguese and, above all, Italian banks at the time.

Table 2. State aid to euro area banks approved by the EC in the years 2008-2017 (EUR billion)

\begin{tabular}{|l|c|c|c|c|}
\hline Form of aid/year & Recapitalisation & $\begin{array}{c}\text { Impaired asset } \\
\text { measures }\end{array}$ & Guarantees & $\begin{array}{c}\text { Other liquidity } \\
\text { measures }\end{array}$ \\
\hline 2008 & 204.9 & 4.8 & 1996.8 & 40.1 \\
\hline 2009 & 38.5 & 90.4 & 9.8 & 0.3 \\
\hline 2010 & 181.1 & 78.0 & 51.5 & 54.9 \\
\hline 2011 & 37.5 & 6.3 & 179.7 & 50.2 \\
\hline 2012 & 121.0 & 155.2 & 206.6 & 35.7 \\
\hline 2013 & 29.6 & 14.7 & 37.9 & 9.7 \\
\hline 2014 & 19.5 & 3.5 & 0.4 & 0.1 \\
\hline 2015 & 18.0 & 0.9 & 127.2 & 0.0 \\
\hline 2016 & 0.8 & 0.0 & 274.1 & 0.0 \\
\hline 2017 & 18.1 & 0.0 & 290.9 & 13.3 \\
\hline
\end{tabular}

Source: author's own calculations based on Internet source 1.

3 Data on GDP were obtained from Eurostat (accessed: 27.08.2019). It should be noted that the aid actually used was smaller. Its value is estimated at ca. EUR 1.962 trillion (cf. Internet source 1). 
Government support for the financial sector can also be assessed in terms of costs for taxpayers. For this purpose, Eurostat data on the impact of government interventions on the balance and debt of the GG sector and contingent liabilities will be used.

Referring to the first two of these categories, Figure 2 shows the impact of interventions on government deficit and debt in relation to GDP in the euro area in the years 2008-2018. The largest increase in the deficit due to support for the financial sector occurred in 2010 and then in 2012. In subsequent years, a reduction of the impact was observed; an increase occurred in 2017, which should be associated with the interventions undertaken by the governments of Italy, Portugal, and Cyprus (EC 2019, p. 4). The impact of aid measures on the debt to GDP ratio reached its highest value in 2012 (slightly over 6\%). In subsequent years, a gradual reduction has been observed.

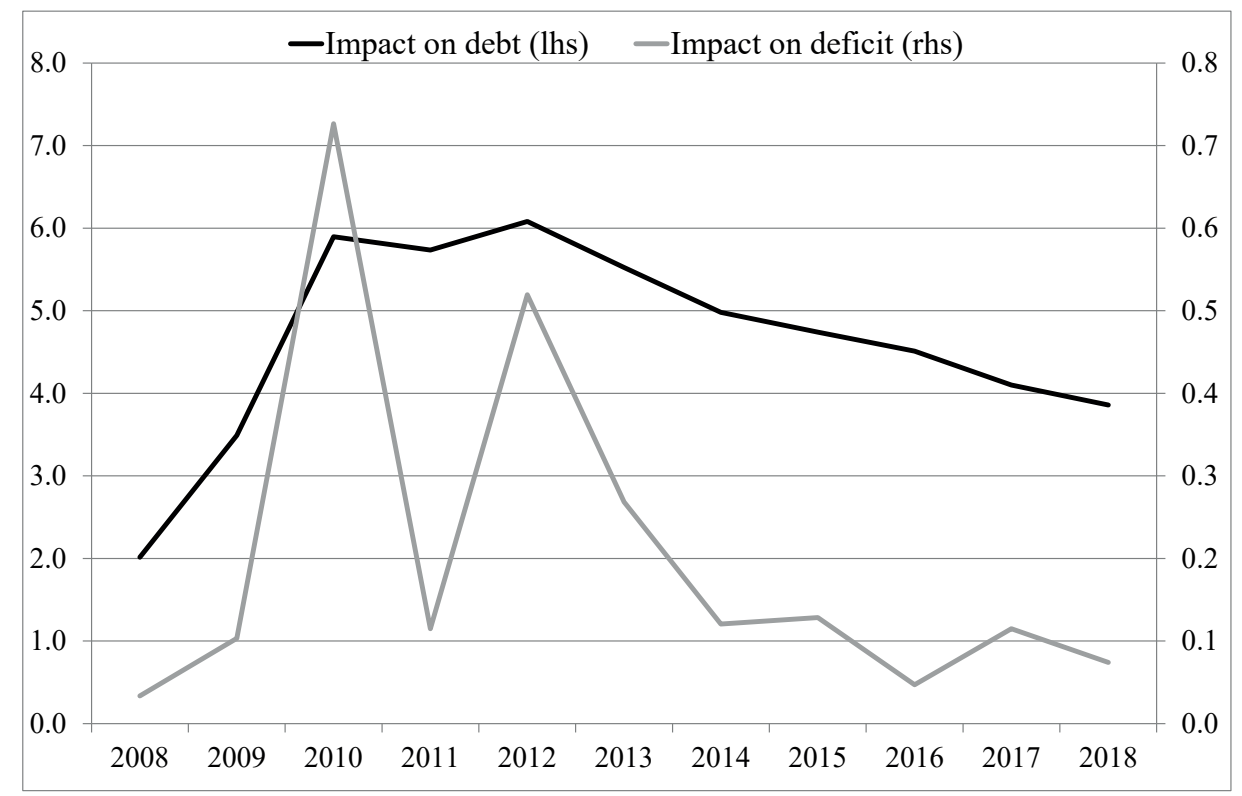

Figure 2. Impact of interventions on government deficit and debt in the years 2008-2018 (\% GDP) Source: author's own calculations based on Eurostat data (accessed: 28.08.2019). Positive values denote an increase in the deficit and debt.

It is worth noting that in the analysed period only four countries - Estonia, Finland, Malta and Slovakia, which together represent 3\% of the euro area GDP - did not need to take any measures that affected their deficit or debt (ECBa 2018, p. 48). At the same time, the size of the interventions, as well as their impact on the balance and debt of the GG sector in individual economies, varied. To illustrate the differences discussed, two groups were created, consisting respectively of the so-called peripheral euro area countries (Cyprus, Greece, Spain, Ireland, Portugal, and Italy) and the economies of the so-called core (Austria, Belgium, France, the Netherlands, Luxembourg, and Germany). Tables 3-4 present the impact of interventions on the balance of the GG 
sector in relation to GDP for both groups. ${ }^{4}$ In the case of the peripheral euro area countries, the impact of interventions was strong. A record high deficit increase (equivalent to $21.2 \%$ of GDP) was recorded in Ireland in 2010. Also noteworthy is the deterioration in the balance of the GG sector in Greece in 2013, and in Cyprus in 2014 and 2018. In the analysed group, it is possible to indicate those countries in which the strongest effects of interventions occurred during the crisis (Ireland) and those struggling with these effects mainly in the post-crisis years (Cyprus, Portugal). In the group of core countries, the impact of interventions on the balance of the GG sector was clearly smaller. In most of these countries, it ranged from -0.2 to $0.2 \%$ of GDP over the vast majority of the period under review. Austria was an exception, as it experienced slightly higher deficit increases - in particular, in 2009 and 2014 (of $0.9 \%$ and 1.6\% of GDP, respectively).

Table 3. Impact of interventions on the balance of the GG sector (\% of GDP): peripheral countries

\begin{tabular}{|c|c|c|c|c|c|c|c|c|c|c|}
\hline Country & 2009 & 2010 & 2011 & 2012 & 2013 & 2014 & 2015 & 2016 & 2017 & 2018 \\
\hline Ireland & -2.21 & -21.19 & -3.73 & 0.20 & 0.24 & 0.01 & -0.70 & -0.01 & -0.11 & -0.11 \\
\hline Greece & 0.16 & 0.42 & 0.31 & -2.80 & -10.76 & 0.08 & -2.73 & 0.20 & -0.06 & -0.05 \\
\hline Spain & 0.06 & 0.07 & -0.33 & -3.68 & -0.32 & -0.13 & -0.05 & -0.21 & -0.04 & -0.01 \\
\hline Italy & 0.00 & 0.01 & 0.01 & 0.03 & 0.04 & 0.05 & -0.05 & 0.00 & -0.33 & 0.02 \\
\hline Cyprus & 0.05 & 0.14 & 0.13 & 0.03 & -0.46 & -8.91 & -1.38 & -0.44 & -0.43 & -8.41 \\
\hline Portugal & 0.01 & -1.23 & -0.49 & -0.56 & -0.39 & -2.96 & -1.58 & -0.19 & -2.34 & -0.77 \\
\hline
\end{tabular}

Source: author's own calculations based on Eurostat data (accessed: 28.08.2019). Negative values denote a deterioration in the balance of the GG sector.

Table 4. Impact of interventions on the balance of the GG sector (\% of GDP): core countries

\begin{tabular}{|c|c|c|c|c|c|c|c|c|c|c|}
\hline Country & 2009 & 2010 & 2011 & 2012 & 2013 & 2014 & 2015 & 2016 & 2017 & 2018 \\
\hline Belgium & 0.00 & 0.08 & -0.15 & -0.59 & 0.15 & -0.02 & -0.04 & -0.07 & 0.04 & 0.07 \\
\hline Germany & -0.12 & -1.29 & 0.01 & -0.05 & 0.05 & 0.01 & 0.00 & -0.07 & -0.06 & -0.18 \\
\hline France & 0.07 & 0.05 & 0.03 & -0.11 & 0.01 & 0.00 & 0.00 & 0.00 & 0.00 & 0.00 \\
\hline Luxembourg & -0.18 & 0.12 & 0.12 & 0.07 & -0.06 & 0.03 & 0.03 & 0.04 & 0.07 & 0.05 \\
\hline Netherlands & -0.37 & -0.17 & -0.02 & -0.03 & -0.18 & -0.01 & 0.06 & 0.05 & 0.06 & 0.09 \\
\hline Austria & -0.92 & -0.11 & -0.09 & -0.41 & -0.46 & -1.60 & -0.65 & -0.07 & -0.09 & -0.06 \\
\hline
\end{tabular}

Source: author's own calculations based on Eurostat data (accessed: 28.08.2019). Negative values denote a deterioration in the balance of the GG sector.

Figure 3 presents the impact of government interventions on the GG debt in the years 2008-2018 for the two groups of countries under consideration. An analysis of the figures allows us to see clear differences. In the case of peripheral euro area economies, the impact was definitely stronger. In all countries under EU/IMF assistance programmes (Greece, Ireland, Portugal, and Cyprus), there were increases that exceeded $10 \%$ of GDP (often multiples of $10 \%$ of GDP). It is worth noting that in some

4 The tables do not include data for 2008 due to the marginal impact of government interventions on the balance at that time in most of the analysed countries. 
of these countries, the impact of interventions on the debt has risen (Portugal, Cyprus) or has remained at a high level (Greece) in recent years. Only Ireland has experienced a clear decline in the impact from a record value (49\% of GDP in 2011). In turn, for most core countries, interventions in the financial sector increased the debt of the GG sector, mainly during the crisis. Since 2013/2014, the impact has been gradually weakening, which has been influenced by the income generated from the aid measures (e.g. dividends received from shares in financial institutions or fees received for public guarantees; ECBa 2018, p. 49).
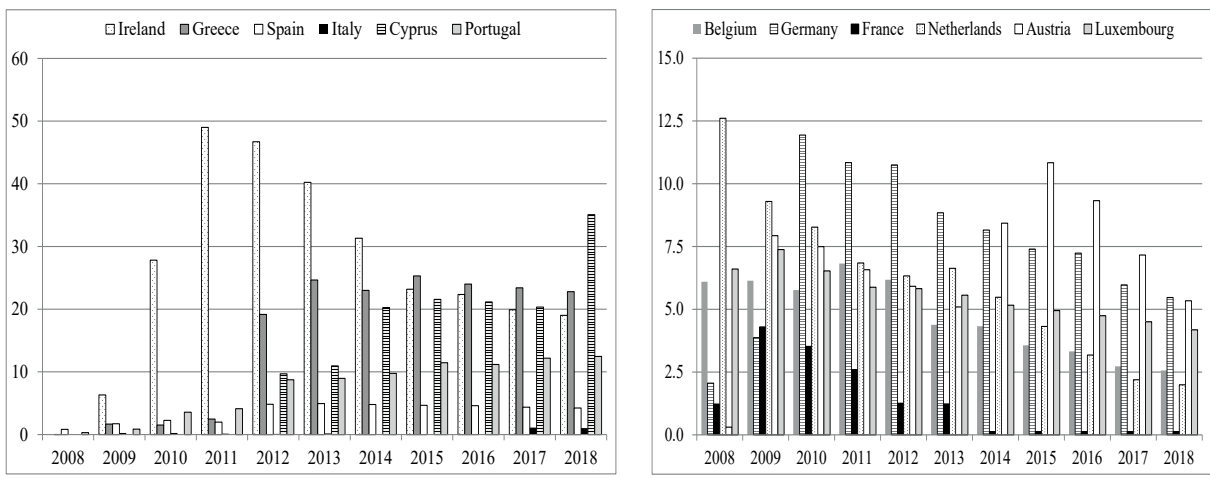

Figure 3. Impact of interventions on government debt (\% of GDP): peripheral and core countries Source: author's own calculations based on Eurostat data (accessed: 28.08.2019).

Figure 4 presents the volume of contingent liabilities in relation to GDP in the analysed EMU countries. As can be seen, in both groups, after increases in the period of highest tensions, a decrease in the analysed ratio is observed. This phenomenon should be assessed positively, as a return to financial stability means that there is no need to renew expiring guarantees. Nevertheless, some guarantees have been called, which means that the reduction in the guarantee was matched by an equivalent increase in government debt and/or deficit (ECBb 2018, p. 50).
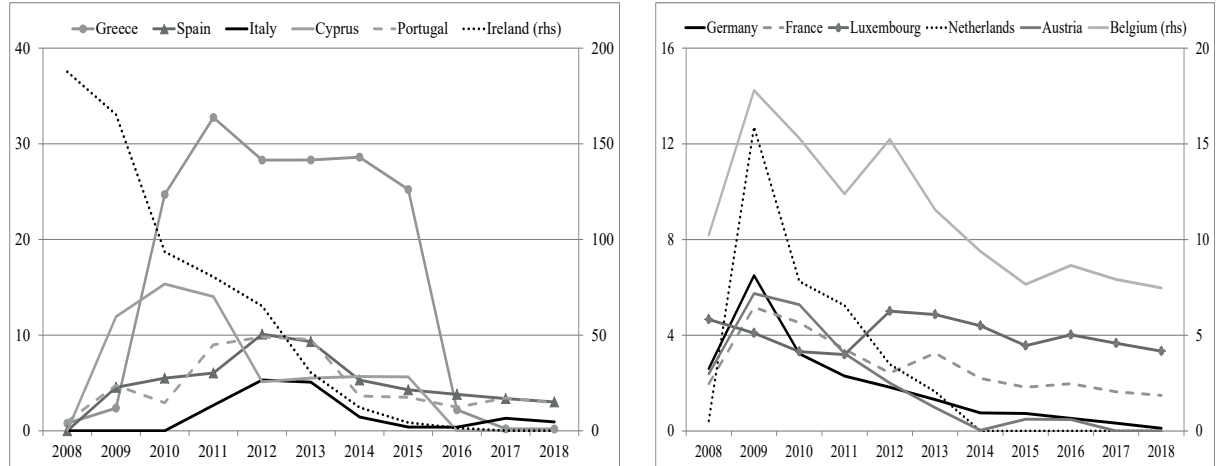

Figure 4. Volume of contingent liabilities (\% of GDP): peripheral and core countries Source: author's own calculations based on Eurostat data (accessed: 28.08.2019). 
Risk transmission from banks to sovereigns has also been the subject of numerous empirical analyses. For example, Gerlach et al. (2010) examined the determinants of sovereign bond spreads in selected euro area countries (vis-à-vis German bunds) in the period January 1999 - February 2009. Their results indicate that in periods of high aggregate risk, countries with larger banking sectors experience higher increases in spreads. This relationship is amplified by low equity ratios in the banking sector. Mody (2009) identified a stronger interdependence between potential government interventions in the banking sector and the state of public finances after the rescue of Bear Stearns in March 2008. It was reflected in growing spreads in the EMU countries with deteriorating prospects for the financial sector. Attinasi et al. (2009), who examined the determinants of spreads in selected euro area countries in the period July 2007 - March 2009, confirmed the occurrence of risk transfer from the private financial sector to the government sector after the announcements of rescue programmes using taxpayers' money. Importantly, the authors conclude that the change in the perception of credit risk of EMU countries was primarily related to the credibility of the announcements of assistance, not its scale (in particular, after excluding Ireland from the sample). Stânga (2014) compared the transfer of risk from the banking sector to the public finance sector generated by the announcements of aid programmes for banks in the USA and six European countries. In general, the results of her study showed stronger contagion in Europe than in the USA. At the same time, the author identified the stabilising effect of the announcements in the form of strong declines in banks' CDS spreads only for the USA. In Europe, this effect proved to be temporary.

In addition, many papers that focus on the mutual nature of feedback loops in the EMU point out that the triggering of the crisis loop was determined by the situation in the banking sector. Acharya et al. (2014), using CDS rates on European sovereigns and banks for 2007-2011, show that changes in the former began to explain changes in the latter after bank bailouts. The results obtained by the authors indicate that the rescue of banks by the euro area countries resulted in an increase in their credit risk, which then weakened the condition of the financial sector. Similar results were obtained by Alter and Schüler (2012) as well as Yu (2017), who also used data from the European CDS market. State aid for banks only temporarily eased tensions in the financial sector at the expense of increased sovereign credit risk. As a result, the increase in fiscal burdens in the EMU became a risk factor for both the governments and banks. A slightly different scheme of contagion is presented in the study of Gómez-Puig et al. (2015). According to their work, after the collapse of Lehman Brothers, interrelationships between the two sectors intensified, with most of the identified episodes of contagion spreading from banks to sovereigns (the reverse flow of risk prevailed up to $2008 \mathrm{Q} 3)$. 


\section{Risk transfer from sovereigns to banks}

Contagion from sovereigns to banks in the EMU is most often considered in the context of banks' exposures to government debt. Although investments in sovereign bonds of advanced economies are widely considered safe (between 1950 and 2010, no OECD country defaulted on its domestic debt; Navaretti 2016, p. 12), the euro area crisis has shown that they are not risk-free.

There is a variety of reasons why commercial banks purchase sovereign bonds. In particular, their demand is associated with managing their inherent maturity mismatches, performing the functions of primary dealers and market makers, using collateral in repo market transactions and transactions with the central bank, and fulfilling prudential requirements (IMF 2012, p. 89). Moreover, sovereign bonds of developed countries, and of issuers of reserve currencies, in particular, hold the special status of safe assets. This means that, among others, they act as safe havens in adverse economic conditions, their yields are used as a proxy for the risk-free rate, and they support the pricing of other assets (cf. BIS 2017).

While commercial banks' motives for holding sovereign debt are well recognised, during the euro area crisis, home bias in banks' holdings of domestic government debt was observed.
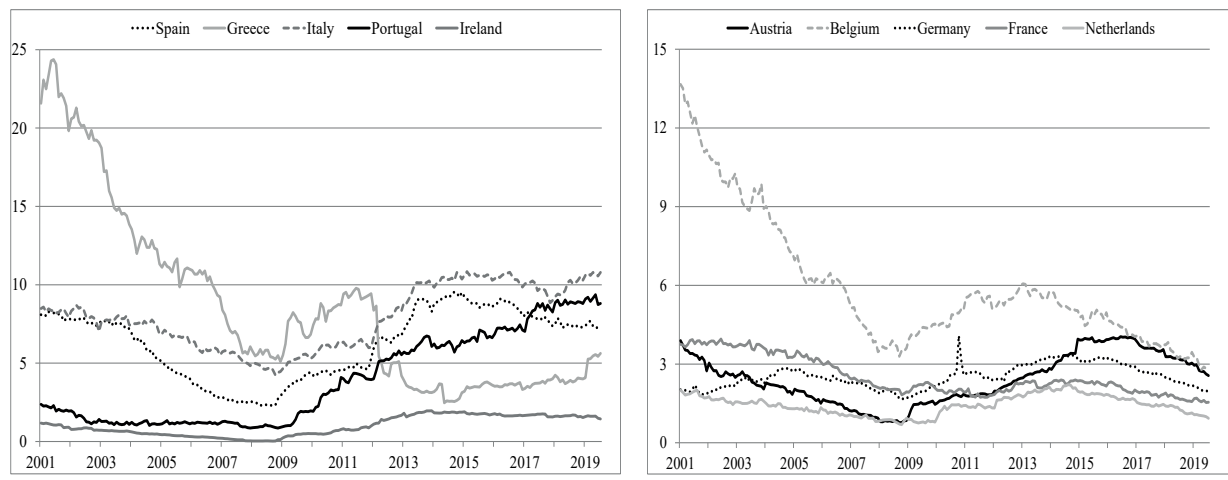

Figure 5. Sovereign exposures of monetary and financial institutions (\% of total assets) Source: author's own calculations based on Eurostat data (accessed: 1.09.2019).

Figure 5 presents the scale of this phenomenon for selected EMU members since 2001. As can be seen, in both the peripheral and the core countries, from the beginning of the common currency area to the outbreak of the global financial crisis, a decrease in the propensity of banks to invest in bonds of their own sovereigns was observed. Since 2008 Q4, a clear change in tendency can be seen, with the scale of the home bias reaching larger proportions in the countries most affected by the sovereign debt crisis, including primarily Italy, Spain, and Portugal. Moreover, in most of these countries, the share of domestic sovereign bonds in total banking sector assets exceeded the level recorded at the beginning of the examined period, which proves financial 
disintegration in the EMU during the crisis. It is also worth noting that the analysed ratio has been decreasing in the group of core countries since 2015/2016; it has reached pre-crisis levels in most of them. In turn, in the majority of peripheral economies, the ratio remains at a high level, with an increase recorded in Italy, Portugal, and Greece at the end of the research period.

To illustrate the risks associated with home bias, the following example can be used. For a hypothetical bank with a leverage ratio of $6.6 \%$ (the bank's assets are 15 times its capital) and exposure to domestic sovereign debt at $10 \%$ (i.e. as in Italy or Portugal), a $10 \%$ loss on sovereign bonds would entail a $15 \%$ capital reduction for the bank (Dell'Ariccia 2018, p. 13).

The question, therefore, arises why during the crisis, banks, especially those from peripheral euro area countries, increased their holdings of domestic sovereign bonds. It seems particularly justified in the context of the growing concerns about the insolvency of these countries at that time, with neither exchange rate risk in the euro area, nor any regulatory framework that would incentivise banks to maintain domestic sovereign exposures as opposed to foreign sovereign exposures (i.e. exposures in other EMU countries). In addition, as noted by Corsetti et al. (2016, p. 21), financial segmentation resulting from the home bias significantly hindered the ECB from pursuing the common monetary policy and achieving its inflation target.

Acharya and Steffen (2015) made an important contribution to the explanation of the home bias in the EMU. They argued that banks with low capital ratios, in search of yield, invested excessively in sovereign bonds of GIIPS countries (Greece, Ireland, Italy, Portugal, Spain), financing their purchase with cheap credit from the ECB (in particular, this was enabled by two 3Y LTROs of December 2011 and February 2012). The authors considered this to be "the greatest carry trade ever".

It should be noted, however, that the carry trade motive only explains why banks from the peripheral euro area countries invested in high-yield GIIPS bonds. It does not indicate why they preferred bonds of their own sovereigns. Some authors see the explanation in moral suasion, which is a form of financial repression that involves the government exerting pressure on financial sector institutions to undertake certain actions. In the context of the EMU crisis, it is argued that banks were under pressure to acquire government debt instruments. Ongena et al. (2016) analysed the behaviour of banks from GIIPS countries in the years 2010-2012. They confirmed the existence of the moral suasion mechanism at times when those countries increased their debt issuance to roll-over maturing debt. State-owned banks and those with low initial holdings of domestic sovereign bonds came under particular pressure.

The role of the political factor (public banks, politicians on the board) as the factor that determines the phenomenon of moral suasion in GIIPS countries was also identified in the works of De Marco and Macchiavelli (2016) as well as Dell'Ariccie et al. (2018). Furthermore, the results of some studies (Navaretti et al. 2016; Altavilla et al. 2017) expand the group of banks under pressure to include those that were previously bailed out. At the same time, there is no consensus in the literature about the 
importance of the ECB's liquidity support as a catalyst for moral suasion. Some works suggest that the fixed-rate full-allotment procedure and two 3-year LTROs facilitated banks' increased exposure to domestic sovereign debt (cf. e.g., Altavilla et al. 2017). However, the link has not been identified in other works (Dell'Ariccia et al. 2018).

Among other potential explanations for the home bias in the euro area, the following two can be identified (Corsetti 2016, p. 19). According to the first interpretation, banks in the peripheral EMU countries could "bet on" preferential treatment by national authorities in the event of a partial default. Moreover, the home bias of banks' sovereign portfolios should motivate the government to repay its debt more than a possible loss of credibility and international sanctions (Gennaioli et al. 2014, p. 1). The other interpretation assumes that banks sought to match the currency of their assets and liabilities in the event that the risk of a return to national currencies materialised.

Assessing the home bias, some authors claim that it was conducive to reducing tensions in the EMU sovereign debt market. As they argue, banks from the peripheral countries played the role of "buyers of last resort" in a situation where other players (foreign banks, insurance companies, money market funds) withdrew from the market. If they had not taken on this role, then yields and spreads would have been even higher, and some countries would have been forced into insolvency (cf. Asonuma et al. 2015; Ongena et al. 2016, p. 36).

In general, however, the conclusions of many studies suggest that the shock absorption effect occurred only in the short term, and home bias in the banks' sovereign debt holdings had a destabilising effect on the functioning of the common currency area (Véron 2017, p. 13). For example, Dell'Ariccia et al. (2018, p. 21) indicate that CDS spreads of banks from GIIPS countries increased along with the increase in the share of domestic sovereign bonds in their assets. The CDS spread for a bank with a $10 \%$ share was higher by 44.3 basis points than for a bank with a $0 \%$ share. According to estimates carried out by Altavilla et al. (2017), conducted for 226 euro area banks in the years 2007-2015, in the stressed euro area countries, banks with higher sovereign debt exposures experienced higher credit risk. In particular, an increase of 100 basis points in the domestic sovereign CDS premium translated into an increase of 31.5 basis points in the CDS premium for banks with a median exposure. The phenomenon of home bias also had a negative impact on credit supply. Altavilla et al. (2017) showed that banks from GIIPS countries with high sovereign exposures reduced lending to the domestic enterprise sector. Lending activity towards local companies was also reduced by subsidiaries of these banks in countries less affected by the crisis. In turn, Grigorian and Manole (2017) showed that home bias negatively affected banks' ability to attract deposits, and consequently their lending, which strengthened the pro-cyclical role of the banking sector in the transmission of fiscal shocks in the EMU. 


\section{Corrective measures}

As already indicated in the Introduction, the construction of the EMU has been widely criticised since the beginning of the common currency area. Its "deficiencies" included a failure to entrust the ECB with the function of LOLR, the absence of a pan-European financial supervisory authority, and the lack of effective mechanisms of risk-sharing (cf. Bordo and Jonung 1999).

As shown by the experience of the crisis, the construction "deficiencies" in the euro area played a role in intensifying the sovereign-bank nexus. It is worth noting that contemporary criticism is in line with negative assessments formulated in the first years of the EMU. For example, Merler and Pisani-Ferry (2012, p. 2) emphasised that in the absence of a supranational banking resolution framework, governments were forced to rescue failing institutions on their own. Given the size of banking systems in the euro area, this meant transferring risk to the public sector. Navaretti et al. (2016, p. 11) indicated that, in addition to the overriding role of deepening macroeconomic imbalances, in particular, fiscal ones, the build-up of negative feedback loop at the beginning of the EMU crisis was determined by the inability of the Eurosystem to play the role of LOLR, the absence of a banking union, and the lack of effective fiscal support mechanism at the euro area level.

Various stabilisation measures were taken in the euro area during the crisis. Some of those measures were launched at the national level, while others were aimed at improving the economic situation of the euro area/EU as a whole. Referring to the latter group, the most important initiatives directly or indirectly aimed at delinking banks from sovereigns include the following:

1. Risk-sharing mechanisms - the temporary European Financial Stability Facility and the permanent European Stability Mechanism (ESM) (operating since 2012). The purpose of their creation was to provide financial support for EMU countries experiencing serious financial difficulties. In the context of the feedback loop problem, it was particularly important to include the instrument of direct recapitalisation of institutions in the ESM lending toolkit in 2014.

2. Fiscal strengthening measures, including, among others, Six-Pack, Two-Pack, and Fiscal Pact.

3. ECB measures - the Enhanced Credit Support (ECS) and entry into the role of LOLR for sovereigns. The ECS was a comprehensive package of measures that focused on providing liquidity to the banking sector. As part of the ECS, euro area banks received unlimited access to central bank liquidity on preferential terms (including longer maturities, reduced collateral requirements, etc.). In turn, the announcement of the OMT programme, associated with the ECB's entry into the role of LOLR for sovereigns, played a key role in reducing tensions in the EMU sovereign bond market. After this event, a permanent decline in spreads was observed, and governments gained additional time to improve the state of public finances. 
4. The Bank Recovery and Resolution Directive (BRRD) that obliged the EU Member States to establish resolution authorities and which specified the objectives, principles, and tools of bank resolution actions. The establishment of the bailin mechanism, which imposes losses on the bank's shareholders and creditors, was particularly important for the feedback loop problem. Thus, bail-in is fundamentally different from bail-out, i.e. the situation when banks were rescued by governments using public funds.

5. Banking union. Its current shape is based on two pillars - the Single Supervisory Mechanism (SSM) (operating since 2014) and the Single Resolution Mechanism (SRM) (fully operational since 2016). The first pillar was created to enhance the supervision of large, cross-border banks, including the solution to the problem of too lenient national supervisors (NBP 2014, pp. 78-79). The other pillar sets out rules for dealing with institutions that are failing or that are likely to fail at the European level. The bank resolution process should be conducted in a way that minimises the effects on the real economy and the state of public finances of the participating countries. The banking union, according to its original assumptions (Van Rompuy 2012), is an unfinished project. The European Deposit Insurance Scheme (EDIS) remains the missing pillar.

In the literature, existing solutions are widely regarded as insufficient. Presented below are proposals being currently discussed to weaken the links between banks and sovereigns.

A large number of these solutions focus on changing regulations that favour the home bias. The principle of zero risk weight for euro area sovereign bonds is particularly criticised. It is argued that this principle does not reflect the actual country credit risk, encourages banks to give preferential treatment to government bonds over other assets (like loans to firms and households), does not create incentives to diversify the investment portfolio, and also allows politicians to resort to moral suasion.

Pagano (2016, pp. 133-134) notes that potential solutions, such as imposing positive risk weights on sovereign debt or introducing limits on banks' exposure towards individual euro area sovereign issuers, are, in practice, difficult to implement. First, as the author points out, regulatory changes of this type would trigger unpredictable adjustments in banks' sovereign portfolios and an increase in the volatility of sovereign bond yields. For example, the application of higher risk weights on peripheral countries' public debt could result in a massive sell-off of these securities and the increased involvement of banks in the bonds of countries with stable macroeconomic foundations. This, in turn, could lead to a new debt crisis in the EMU. Secondly, the concerns of policymakers from GIIPS countries that the reduction in demand for domestic sovereign bonds as a result of the discussed regulatory changes would result in permanently higher debt servicing costs and limited possibilities of resorting to moral suasion play a large role.

The proposal to create sovereign bond-backed securities (SBBS) is a kind of response to the above-presented concerns (cf. Brunnermeier et al. 2016; ESRB 2018). The issuers 
of these assets, i.e. private or public financial institutions (such as the European Investment Bank), would buy a diversified portfolio of euro-denominated central government bonds (the shares would be defined by the ECB capital key) and they would use it as collateral to issue their own securities. The project provides for two tranches - a senior one (senior SBBS tranche) and a junior one (junior SBBS tranche). ${ }^{5}$ The first of the tranches would be protected against losses of up to $30 \%$ on the underlying bond portfolio, which would allow it to perform the function of safe assets for the euro area. The other would be much riskier. As the proponents of the project argue, risk diversification in the underlying portfolio would weaken the link between banks and their governments. In particular, in times of stress, the destabilising capital flows from countries with worse macroeconomic foundations to so-called safe havens would be replaced by the flow of capital from more to less risky asset classes, i.e. from junior SBBS to senior SBBS.

Other suggestions can be found in the work of Véron (2017). He takes the view that, despite the initial successes of the banking union, its aim, i.e. breaking the vicious circle between banks and sovereigns, has not been achieved. In his assessment, the priority is to reduce the home bias in investors' portfolios, which can be accomplished by simultaneously completing the banking union, i.e. the creation of EDIS in line with the EC's original proposal (EC 2015), and introducing regulatory changes aimed at reducing highly concentrated sovereign exposures. He argues that EDIS has not been established due to suspicion that financially stressed countries would exert pressure on banks to use deposits protected by EDIS to increase their purchases of bonds issued by these countries' governments. Therefore, an indispensable part of the proposal is the introduction of sovereign exposure limits. The author postulates a system of charges for concentration exposures to individual euro area countries which would increase after exceeding pre-defined thresholds. The expected effect of the regulation would be a reduction in the share of domestic sovereign bonds in banks' investment portfolios and an increase in the share of bonds of other members of the EMU.

\section{Conclusions}

The negative feedback loop between banks and sovereigns characterised the crisis in the euro area. Strong interdependences between these sectors were determined by, among others, the dominant role of banks in the EMU financial system, growing macroeconomic imbalances in some economies, as well as "deficiencies" in the institutional architecture of the euro area.

The transfer of risk between the analysed sectors was bilateral. In the phase of the global financial crisis, the governments intervened to rescue banks using taxpayers' money, which translated into a deterioration of the state of public finances. In turn,

5 To be precise, in the ESRB project, subordinated securities are divided into mezzanine security and junior security. 
during the sovereign debt crisis phase, the negative consequences of excessive exposures of banks towards domestic sovereign issuers were revealed.

As regards the post-crisis situation, a reduction in interconnectedness has been observed in recent years. In particular, this is evidenced by a smaller size of public aid for the banking sector, and consequently, a weaker impact of interventions on the debt and balance of the GG sector, a decreasing level of contingent liabilities, as well as a reduction in the home bias phenomenon. However, this does not mean that all EMU countries have experienced an even reduction in the risk of restarting the crisis loop. The results of the analysis clearly show the differences between the so-called core and periphery of the EMU. In the case of the latter group, it is possible to indicate countries for which some indicators that determine their vulnerability to feedback loops (such as the ratio of public debt to GDP or the share of government bonds issued by own government in the assets of the domestic banking sector) are less favourable than before the outbreak of the crisis.

Since the outbreak of the crisis, the euro area countries have introduced various measures explicitly or implicitly aimed at breaking the "vicious circle between banks and sovereigns". These include, among others, the establishment of the ESM, the ECB's adoption of the role of the LOLR, and the launch of the banking union. All these measures constituted an important response to the crisis, but they cannot be regarded as enough to break the strong interdependence between the two sectors and thus protect the EMU from future crises.

The home bias in debt securities holdings remains a particular challenge; hence many recent proposals concentrate on solving this problem. The restriction of the principle of zero-risk weight for sovereign exposures, completing the banking union by establishing EDIS, and creating a "safe asset" for the euro area are among them. It is likely, however, that attempts to implement them would encounter political resistance at the national level.

All in all, the study contributes to the existing literature on the negative feedback loop between banks and sovereigns in the euro area by adopting a post-crisis perspective and assessing this phenomenon in relation to the crisis period. The results show that in the post-crisis conditions, a reduction in interconnectedness has been observed, although it has been experienced to a greater extent by the core than the peripheral euro area countries. At the same time, despite some progress in recent years, institutional reforms aimed at breaking the sovereign-bank nexus are far from complete. Therefore, the results of the study support the research hypothesis that the EMU remains vulnerable to the mutual transfer of risks generated in each of these sectors. 


\section{References}

Acharya, V., Steffen, S. (2015), The "greatest" carry trade ever? Understanding eurozone bank risks, "Journal of Financial Economics", 115 (2). https://doi.org/10.1016 /j.jfineco.2014.11.004

Acharya, V., Drechsler, I., Schnabl, P. (2014), A Pyrrhic Victory? Bank Bailouts and Sovereign Credit Risk, “The Journal of Finance”, 69 (6). https://doi.org/10.1111/jofi.12206

Altavilla, C., Pagano, M., Simonelli, S. (2016), Bank exposures and sovereign stress transmission, ECB Working Paper 1969, October 2016. https://doi.org/10.2139/ss rn.2848937

Alter, A., Schüler, Y. (2012), Credit spread interdependencies of European states and banks during the financial crisis, "Journal of Banking \& Finance", 36 (12). https:// doi.org/10.1016/j.jbankfin.2012.08.002

Asonuma, T., Bakhache, S., Hesse, H. (2015), Is Banks Home Bias Good or Bad for Public Debt Sustainability?, IMF Working Paper WP/15/44. IMF. https://doi.org/10.50 89/9781498323505.001

Attinasi, M., Checherita, C., Nickel, C. (2009), What explains the surge in euro area sovereign spreads during the financial crisis of 2007-09?, ECB Working Paper Series, Frankfurt am Main: ECB.

Bekooij, J., Frost, J., van der Molen, R., Muzalewski, K. (2016), Hazardous tango: Sovereign-bank interdependencies across countries and time, DNB Working Paper No. 541/ December 2016, Amsterdam. https://doi.org/10.2139/ssrn.2891296

BIS (2017). The regulatory treatment of sovereign exposures.

Bordo, M., Jonung, L. (1999), The Future of EMU: What Does the History of Monetary Unions Tell Us?, NBER Working Paper No. 7365. https://doi.org/10.3386/w7365

Brunnermeier, M., Langfield, S., Pagano, M., Reis, R., Van Nieuwerburgh, S., Vayanos, D. (2016), ESBies: Safety in the tranches, Working Paper Series No. 21 / September 2016. https://doi.org/10.2139/ssrn.2840935

Corsetti, G., Feld, L., Koijen, R., Reichlin, L., Reis, R., Rey, H., Weder, B. (2016), Reinforcing the Eurozone and Protecting an Open Society, London: CEPR.

Cour-Thimann, P., Winkler, B. (2013), The ECB's non-standard monetary policy measures: the role of institutional factors and financial structure, ECB Working Paper Series No. 1528 / April 2013, Frankfurt am Main: ECB.

De Marco, F., Macchiavelli, M. (2016), The Political Origin of Home Bias: the case of Europe, Finance and Economics Discussion Series 2016-060, Washington: Board of Governors of the Federal Reserve System. https://doi.org/10.17016/feds.2016.060

De Paoli, B., Hoggarth, G., Saporta, V. (2009), Output costs of sovereign crises: some empirical estimates, Bank of England Working Paper No. 362 / February 2009, London: Bank of England. https://doi.org/10.2139/ssrn.1344294

Dell'Ariccia, G., Ferreira, C., Jenkinson, N., Laeven, L., Martin, A., Minoiu, C., Popov, A. (2018), Managing the sovereign-bank nexus, Working Paper Series No. 2177 / September 2018. Frankfurt am Main: ECB. https://doi.org/10.5089/97814843596 24.087

EC (2011), The effects of temporary State aid rules adopted in the context of the financial and economic crisis, Commission Staff Working Paper October 2011, Brussels. 
EC (2015), A stronger Banking Union: New measures to reinforce deposit protection and further reduce banking risks. https://europa.eu/rapid/press-release_IP-15-6152_pl .htm (accessed: 30.09.2019).

EC (2019), Eurostat Supplementary Table For Reporting Government Interventions To Support Financial Institutions, Background note (April 2019).

ECB (2018a), ECB Economic Bulletin, Issue 6/2018, Frankfurt am Main: ECB.

ECB (2018b), Financial integration in Europe, May 2018, Frankfurt am Main: ECB.

ESRB (2018), Sovereign bond-backed securities: a feasibility study, Frankfurt am Main: ESRB.

Euro Area Summit Statement (2012).

Flejterski, S. (2008), Zaufanie do instytucji bankowo-finansowych jako fundament stabilnego systemu finansowego [in:] J. Nowakowski, T. Famulska (eds), Stabilność i bezpieczeństwo systemu bankowego, Difin S.A., Warszawa.

Gennaioli, N., Martin, A., Rossi, S. (2014), Sovereign Default, Domestic Banks, and Financial Institutions, “The Journal of Finance”, 69 (2). https://doi.org/10.1111/jo fi.12124

Gerlach, S., Schulz, A., Wolff, G. (2010), Banking and sovereign risk in the euro area, Discussion Paper Series 1: Economic Studies No. 09/2010, Frankfurt am Main: Deutsche Bundesbank.

Gómez-Puig, M., Sosvilla-Rivero, S., Singh, M. (2015), Sovereigns and Banks in the Euro Area: A Tale of Two Crises, SSRN Electronic Journal. https://doi.org/10.2139 /ssrn.2548460

Grigorian, D., Manole, V. (2017), Sovereign risk and deposit dynamics: evidence from Europe, “Applied Economics", 49 (29). https://doi.org/10.1080/00036846.2016.124 8358

https://ec.europa.eu/competition/state_aid/scoreboard/index_en.html (accessed: 20.08.2019)

IMF (2012), Global Financial Stability Report - The Quest for Lasting Stability, Washington, DC: IMF.

Luitel, P., Vanpée, R., De Moor, L. (2016), Pernicious effects: How the credit rating agencies disadvantage emerging markets, "Research in International Business and Finance”, 38. https://doi.org/10.1016/j.ribaf.2016.04.009

Merler, S., Pisani-Ferry, J. (2012), Hazardous tango: sovereign-bank interdependence and financial stability in the euro area, Financial Stability Review No.16 April 2012, Banque de France.

Mody, A. (2009), From Bear Stearns to Anglo Irish: How Eurozone Sovereign Spreads Related to Financial Sector Vulnerability, IMF Working Paper WP/09/108. https:// doi.org/10.5089/9781451872552.001

Navaretti, G., Calzolari, G., Pozzolo, A. (2016), Diabolic Loop or Incomplete Union? Sovereign and Banking Risk, "European Economy", 1.

NBP (2014), Ekonomiczne wyzwania integracji Polski ze strefa euro, Warszawa: NBP.

Ongena, S., Popov, A., Van Horen, N. (2016), The invisible hand of the government: "Moral suasion" during the European sovereign debt crisis, ECB Working Paper No. 1937 / July 2016. Frankfurt am Main: ECB. https://doi.org/10.2139/ssrn.2745767 
Reinhart, C., Rogoff, K. (2011), From Financial Crash to Debt Crisis, "American Economic Review", 101 (5). https://doi.org/10.1257/aer.101.5.1676

Singh, A., Ulargui, I., Sabbione, P., Jezek, M., Hanamante, A., O-Toole, C. (2019), How to fix European banking ... and why it matters, Thematic Research, Deutsche Bank.

Stângă, I. (2014), Bank bailouts and bank-sovereign risk contagion channels, "Journal of International Money and Finance”, 48. https://doi.org/10.1016/j.jimonfin.2014 .07 .005

Véron, N. (2017), Sovereign Concentration Charges: A New Regime for Banks Sovereign Exposures, Brussels: European Parliament.

$\mathrm{Yu}, \mathrm{S}$. (2017), Sovereign and bank Interdependencies-Evidence from the CDS market, "Research in International Business and Finance", 39. https://doi.org/10.1016/j.ri baf.2016.07.033

\section{Streszczenie}

\section{Negatywne sprzężenia zwrotne między sektorem bankowym i sektorem finansów publicznych w strefie euro. Doświadczenia kryzysu i perspektywa pokryzysowa}

Przebieg kryzysu w strefie euro charakteryzowało zjawisko negatywnych sprzężeń zwrotnych między sektorem bankowym a sektorem finansów publicznych. Silne zależności między tymi sektorami warunkowała m.in. dominująca rola banków w systemie finansowym UGiW, narastające nierównowagi makroekonomiczne, a także „braki” $\mathrm{w}$ architekturze instytucjonalnej strefy euro. $\mathrm{W}$ artykule przedstawiona jest geneza omawianego zjawiska w UGiW, a także istota i skala obustronnego transferu ryzyka w czasie kryzysu i w latach pokryzysowych. Dodatkowo, omówiono dotychczasowe działania w kierunku ograniczenia negatywnych sprzężeń, a także wskazano pozostające wyzwania w tym obszarze.

Słowa kluczowe: efekt zarażania, kryzys w strefie euro, aktywa bezpieczne

JEL: F15, F36, F45 